\title{
VENÄJä JA EuROOPPA \\ IGOR GANIKOVSKIN KOLLAASEISSA
}

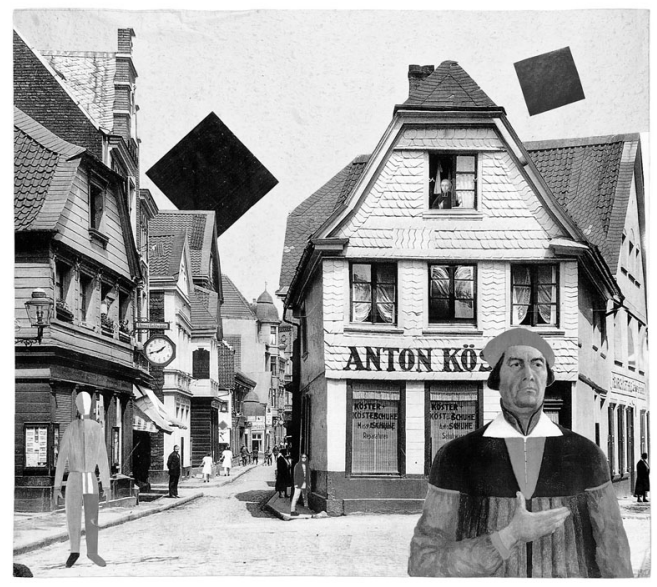

Igor Ganikovski: Old Bochum I, kollaasi, 1997, 52 x $58 \mathrm{~cm}$.

Taiteilija Igor Ganikovski (s. 1950) on syntyperäinen moskovalainen mutta nykyisin Saksan kansalainen. Moskovassa 1980-luvulla hän ravisteli yhdessä Jevgeni Dibskyn ja Zahar Shermanin kanssa maalaustaiteen neuvostokonventioita yksilöllisen ilmaisun lähtökohdista. Juutalaisuus ja venäläinen avantgarde ovat olleet Ganikovskin karhean taiteen henkistä maaperää. Maalauksen ja kollaasitekniikan yhdistäminen on hänelle tunnusomaista, ja samaa materiaalista otetta ilmentävät myös hänen maalatut konstruktiiviset reliefinsä ja veistoksensa.

Ganikovskin kollaasisarja vuodelta 1997 on taiteilijan saksalaisen elämäntilanteen tarkastelua venäläisin silmälasein. Teoksissaan Old Bochum I ja II hän antaa Kazimir Malevitshin taiteen ihmishahmojen ja leijuvien neliöiden lomittua anonyymeihin valokuviin Bochumista ehkä 1920-luvulta. Augustsandermainen tupakkakauppias perheineen on saanut asiakkaakseen venäläisen avantgarden ikonin. Yhteentörmäys on hellä ja huumorintajuinen. Siellä täällä vilahtavat luottokorttien tunnukset kertovat talouden realiteeteista ja tuovat kuvat nykyaikaan. Walking-kollaasissa Bochumin kattojen takaa kohoaa Kremlin torni tähtineen ja katuvilinässä astelee Stalin marsalkkoineen, samalla kun nykyaikaiset tuotemerkit täplittävät rakennusten seiniä.

Menestys Saksassa mahdollisti taiteilijan lomamatkat Välimeren maihin. Composition I ja II kuten myös Visitor-kollaaseissa hänen mielikuvituksensa Malevitsheineen ja Stalineineen kietoutuu eteläespanjalaisen pikkukaupungin katukuvaan. Yökerhon hälyn lisäksi myös Leninin agitaatio kantautuu lomaparatiisiin, ja Kremlin torni pistää esiin maurilaisen muurinharjan takaa.

Malevitsh on poissaolevana läsnä oleva myös Ganikovskin Portrey I ja II-kollaaseissa. Itse asiassa venäläinen suprematisti sananmukaisesti loistaa poissaolollaan. Hänen taustastaan irtileikattu omakuvansa antaa muodon kollaasien keskushahmolle, ja poissaolevan tilalla on saksalaisten ja espanjalaisten kaupunkiaiheiden runollinen fuusio.

Ganikovskin kollaasit ovat venäläisen perinteen ja länsieurooppalaisuuden vuoropuhelua, jota emigrantin koti-ikävän ja voitetun vapauden hedelmällinen myllerrys siivittää. 